\title{
SOCIO-ECONOMIC DETERMINANTS OF OFF-FARM ACTIVITY PARTICIPATION IN BANGLADESH
}

\author{
M.S. Rahman, Assistant Professor \\ Department of Management and Finance, Faculty of Agribusiness Management \\ Sher-e Bangla Agricultural University, Dhaka, Bangladesh \\ E-mail: saadrhmn@yahoo.com
}

\begin{abstract}
The study was conducted in two districts of Bangladesh to determine the factors affecting the participation in off-farm activity. A total of 150 sample farmers were selected for interview through random sampling technique. The results showed that the average annual income was higher for service holders $($ Tk.1,83,696) compared to business $($ Tk. 1,69,215) and offfarm labour activities (Tk.1,09,373). Participations in activities like business and services were positively influenced by the farm size and education respectively. On the other hand, farm size and education were inversely related with participation in off-farm labour activities. Farmers in the study areas mentioned low income from agriculture as a reason for participating in off-farm activity.
\end{abstract}

\section{KEY WORDS}

Household income; Off-farm income; Service; Off-farm labour; Determinants.

Due to economic pressure, many households often search for alternative means like off-farm activities to cope with the problem of income variability. Off-farm activities have become an important component of livelihood strategies among rural households in our country. Several studies have reported a substantial and increasing share of off-farm income in total household income (Haggblade et al, 2007). The role of off-farm activities in promoting growth of rural economy and reducing poverty is well documented (Child and Kaneda, 1975; Islam, 1984; Ranis and Stewart, 1993; Reardon, 1997; Weijland, 1999; Lanjouw, 2001). Rural off-farm sector encompasses generally all non crop activities that are not directly related to crop and non crop production operations but are carried out as backward-forward linkages to the various enterprises with in the rural areas proper and also in the small urban and peri urban areas of large metropolitan (Mandal, 2002).

Diversifying one's sources of income has become a major challenge in Bangladesh in recent years. Compared to the agricultural sector, employment opportunities in the off-farm sector have been increasing rapidly since the early nineties (The Financial Express, 2012). The Government of Bangladesh in its national poverty reduction strategy paper identified the off-farm sector as a "leading sector" in the rural economy (GOB, 2005). There are several studies (Islam, 1984; Hossain et al, 1994; Bhattacharya, 1996; Khandker, 1996; Hossain, 2005) reviewed the off-farm sector in Bangladesh. The purpose of this paper is to provide additional information on off-farm activity in rural areas of Bangladesh for assessing the recent status of off-farm activity. Keeping these factors in consideration the present study was undertaken with the following specific objectives.

Specific Objectives:

1. To examine the structure of rural household incomes in the study areas;

2. To find out factors affecting household participation in off-farm activities; and

3. To find out the reasons for participating in off-farm activities.

\section{METHODOLOGY}

The study was conducted in two districts namely Jessore and Rangpur due to high concentration of off-farm activities. Rural off-farm activities in the study areas were classified into three categories; i) Business enterprises such as shop keeping, petty trading, contractor services etc; ii) Services such as salaried service in public and private sector institutions, teachers, lawyer, village doctors etc and iii) Off-farm labour such as mechanics, wage employment in rural business, transport operations, construction labour etc. A total of 150 
samples taking 25 from each group and 75 from each district were selected randomly for this study. The study was mainly based on primary data collected through face to face interview during the month of March to May, 2011. The collected data were then edited and processed to fulfill the objectives of the study.

Analytical technique. Descriptive statistics were used to analyze the annual household income of the sample farmers. The probit model was used to identify the factors influencing the participation in off-farm activities; a binary choice model based on the method of maximum likelihood is specified. The dependent variable of these models was participation in off-farm activities. Since the dependent variable was dichotomous, OLS cannot be used. Therefore, the following type of probit model was used for this study.

$$
\begin{gathered}
Y_{i}^{*}=\beta X_{i}+u_{i} \text {, where } u_{i} \sim N(0,1), i=1, \ldots . n \\
Y=1_{\left\{Y^{*}>0\right\}}=1 \text { if } Y^{*}>0 \\
0 \text { Otherwise }
\end{gathered}
$$

Where, $Y_{i}=$ Farmers participating in the off-farm activities (if participate $=1$; other wise $=0$ ), $X_{i}=$ Independent variables. Three separate models for this purpose were run for three categories of off-farm activity like (i) Business activities (ii) Services, and (iii) Off-farm labour.

\section{Variable used in the probit model and their measurement:}

Age $\left(X_{1}\right)$ : Respondent's age in year was directly inserted in the model. This variable could have a positive or negative effect on the respondent's decision to participate in the offfarm activities.

Farm size $\left(\mathrm{X}_{2}\right)$ : Farm size is an indicator of social status of the respondents. It was calculated on per hectare basis for each respondent.

Household workers $\left(\mathrm{X}_{3}\right)$ : It was measured on the basis of number of earning members in the family.

Dependency ratio $\left(\mathrm{X}_{4}\right)$ : It is the ratio of total number of family members and earning members of the family.

Organizational participation $\left(X_{5}\right)$ : It was measured on basis of participation in the different organization. A respondent was given a score of one if he is a member of any organization, otherwise 0 .

Infrastructure development $\left(\mathrm{X}_{6}\right)$ : In this study development of road and highways was considered as a proxy of infrastructure development. A score of 1 is given if the respondents have the facilities to use the roads and highways, otherwise 0.

Education $\left(\mathrm{X}_{7}\right)$ : Education of the respondent was measured on the basis of total schooling years.

\section{RESULTS AND DISCUSSION}

Average annual income of the respondents. Average annual income was found higher for service holders (Tk. 183696) than that of business (Tk. 169215) and off-farm labour (Tk. 109373). Among the service holders higher income was found for the respondents of Rangpur compared to Jessore. Out of the total income, highest portion of the income comes from off-farm income activities compared to agricultural income for all categories of respondents. Service holders of Jessore received highest $68 \%$ of their total income from off-farm activities compared to the service holders of Rangpur (see Table 1).

Factors affecting participation in off-farm activities. The parameters of the Probit model estimated to identify the factor influencing participation in off-farm activities are presented in Table 2, 3 and 4.

The intensity of participation in business activities is positively related with farm size, organization participation and infrastructure development. If the farm size increases by $1 \%$, keeping other factors constant, the probability of participating in business activities would increase by $0.60 \%$. This may be for the fact that if farm size increases respondents may earn more money by producing more crops in the field. As a result they can invest this extra money in their business activities. Similarly, if the respondents can avail developed 
infrastructure like road and highways they can easily communicate with other areas and increase their volume of business (see Table 2).

Table 1. Average annual income of different categories of respondents

\begin{tabular}{|c|c|c|c|c|c|c|c|c|c|}
\hline \multirow{2}{*}{ Sources } & \multicolumn{3}{|c|}{ Business } & \multicolumn{3}{|c|}{ Service } & \multicolumn{3}{|c|}{ Off-farm } \\
\hline & $\mathrm{j}$ & $\mathrm{R}$ & Aill & $\mathrm{J}$ & $\mathrm{R}$ & Aill & $\mathrm{j}$ & $\mathrm{R}$ & Aili \\
\hline \multicolumn{10}{|c|}{ A. Agricultural income (Tk) } \\
\hline Crop sector & 54162 & 77943 & 66052 & 40997 & 76962 & 58980 & 36132 & 41213 & 38672 \\
\hline Livestock & 9605 & 9988 & 9796 & 4620 & 11596 & 8108 & 10795 & 8991 & 9893 \\
\hline Poultry & 665 & 428 & 547 & 596 & 304 & 450 & 852 & 490 & 671 \\
\hline Fisheries & 1260 & 3140 & 2200 & 1060 & 1280 & 1170 & 800 & 600 & 700 \\
\hline Others & 3880 & - & 1940 & 8780 & 980 & 4880 & 1600 & 28 & 814 \\
\hline Sub Total & $\begin{array}{c}69572 \\
(50)\end{array}$ & $\begin{array}{c}91499 \\
(46)\end{array}$ & $\begin{array}{c}80535 \\
(48)\end{array}$ & $\begin{array}{c}56053 \\
(32)\end{array}$ & $\begin{array}{c}91122 \\
(47)\end{array}$ & $\begin{array}{c}73588 \\
(40)\end{array}$ & $\begin{array}{c}50179 \\
(45)\end{array}$ & $\begin{array}{c}51322 \\
(47)\end{array}$ & $\begin{array}{c}50750 \\
(46)\end{array}$ \\
\hline \multicolumn{10}{|c|}{ B. Off-farm income (Tk) } \\
\hline Business & 68880 & 108480 & 88680 & - & - & $\overline{-}$ & - & - & - \\
\hline Service & - & - & - & 118248 & 101969 & 110108 & - & - & - \\
\hline $\begin{array}{l}\text { Off-farm } \\
\text { labour }\end{array}$ & - & - & - & - & - & - & 60222 & 57024 & 58623 \\
\hline Sub Total & $\begin{array}{c}68880 \\
(50)\end{array}$ & $\begin{array}{c}108480 \\
(54)\end{array}$ & $\begin{array}{c}88680 \\
(52)\end{array}$ & $\begin{array}{c}118248 \\
(68)\end{array}$ & $\begin{array}{c}101969 \\
(53)\end{array}$ & $\begin{array}{c}110108 \\
(60)\end{array}$ & $\begin{array}{c}60222 \\
(55)\end{array}$ & $\begin{array}{c}57024 \\
(53)\end{array}$ & $\begin{array}{c}58623 \\
(54)\end{array}$ \\
\hline $\begin{array}{l}\text { Grand total } \\
(A+B)\end{array}$ & $\begin{array}{c}138452 \\
(100)\end{array}$ & $\begin{array}{c}199979 \\
(100)\end{array}$ & $\begin{array}{c}169215 \\
(100)\end{array}$ & $\begin{array}{c}174301 \\
(100)\end{array}$ & $\begin{array}{c}193091 \\
(100)\end{array}$ & $\begin{array}{c}183696 \\
(100)\end{array}$ & $\begin{array}{c}110401 \\
(100)\end{array}$ & $\begin{array}{c}108346 \\
(100)\end{array}$ & $\begin{array}{c}109373 \\
(100)\end{array}$ \\
\hline
\end{tabular}

Note: $J=$ Jessore, $R=$ Rangpur, Figures in the parentheses indicates percentage of grand total

Table 2. Factors affecting participation in business activities: estimates of a probit model

\begin{tabular}{|c|c|c|c|c|}
\hline Factors & Coefficients & Standard error & z-value & Marginal effect \\
\hline Education & 0.004 & 0.03 & 0.17 & 0.0016 \\
\hline Age & 0.004 & 0.01 & 0.37 & 0.0014 \\
\hline Farm size & $0.601^{\star \star}$ & 0.23 & 2.50 & $0.2027^{\star \star}$ \\
\hline Household workers & 0.004 & 0.11 & 0.03 & 0.0013 \\
\hline Dependency ratio & 0.19 & 0.14 & 1.53 & 0.0652 \\
\hline Organizational participation & $0.75^{\star \star}$ & 0.27 & 2.92 & $0.2401^{\star \star \star}$ \\
\hline Infrastructure development & $1.27^{\star \star \star \star}$ & 0.35 & 3.71 & $0.3392^{\star \star \star}$ \\
\hline Constant & $-1.93^{\star \star}$ & 0.85 & -2.39 & - \\
\hline Log likelihood function & \multicolumn{4}{|c|}{-75.16} \\
\hline LR chi2 & \multicolumn{4}{|c|}{40.62} \\
\hline Prod >chi2 & \multicolumn{4}{|c|}{0.000} \\
\hline Pseudo $\mathrm{R}^{2}$ & \multicolumn{4}{|c|}{0.21} \\
\hline Observations (n) & \multicolumn{4}{|c|}{150} \\
\hline
\end{tabular}

In the case of service, education plays a positive and significant role. The respondents having higher education are encouraged to participate in services. If the education is increased by $1 \%$, keeping other factors constant, the probability of participation in services would increase by $0.20 \%$. Dependency ratio also positively associated with the participation in services. On the other hand, organizational participation is negatively related with services due to the fact that organizational participation requires additional time which restricts the service holders to take part in this kind of activity (see Table 3).

Most of the factors included in the model are negatively associated with the participation in off-farm labour activities. The negative association with age indicates the preference of the younger generation for off-farm jobs over agricultural wage labour. Negative association with farm size indicates that if the respondents have more land they can produce more crop and earn money from selling this crops. Organizational participation and infrastructure development were also negatively associated with off-farm labour activities. Negative association of education indicates educated persons are more comfortable with service sector compared to off-farm labour activities (see Table 4). 
Table 3. Factors affecting participation in different services: estimates of a probit model

\begin{tabular}{|c|c|c|c|c|}
\hline Factors & Coefficients & Standard error & z-value & Marginal effect \\
\hline Education & $0.207^{* \star *}$ & 0.04 & 5.72 & $0.0704^{* \star}$ \\
\hline Age & 0.005 & 0.01 & 0.50 & 0.0020 \\
\hline Farm size & -0.150 & 0.23 & -0.68 & -0.0513 \\
\hline Household workers & 0.148 & 0.15 & 1.13 & 0.0504 \\
\hline Dependency ratio & $0.288^{* \star}$ & 0.14 & 2.32 & $0.0981^{\star \star}$ \\
\hline Organizational participation & $-0.419^{*}$ & 0.27 & -1.63 & $-0.145^{\star}$ \\
\hline Infrastructure development & -0.386 & 0.29 & -1.38 & -0.136 \\
\hline Constant & $-2.90^{\star \star \star}$ & 0.77 & -3.55 & - \\
\hline Log likelihood function & \multicolumn{4}{|c|}{-69.40} \\
\hline LR chi2 & \multicolumn{4}{|c|}{52.15} \\
\hline Prod $>$ chi2 & \multicolumn{4}{|c|}{0.000} \\
\hline Pseudo $\mathrm{R}^{2-}$ & \multicolumn{4}{|c|}{0.27} \\
\hline Observations (n) & \multicolumn{4}{|c|}{150} \\
\hline
\end{tabular}

Table 4. Factors affecting participation in off-farm labour activities: estimates of a probit model

\begin{tabular}{|c|c|c|c|c|}
\hline Factors & Coefficients & Standard error & z-value & Marginal effect \\
\hline Education & $-0.23^{\star \star \star}$ & 0.04 & -5.49 & $-0.060^{\star \star \star}$ \\
\hline Age & $-0.22^{*}$ & 0.01 & -1.60 & $-0.005^{*}$ \\
\hline Farm size & $-1.43^{\star \star}$ & 0.61 & -2.34 & $-0.374^{\star *}$ \\
\hline Household workers & 0.18 & 0.15 & 1.14 & 0.047 \\
\hline Dependency ratio & 0.21 & 0.15 & 1.41 & 0.055 \\
\hline Organizational participation & -0.33 & 0.29 & -1.12 & -0.088 \\
\hline Infrastructure development & $-0.93^{\star \star}$ & 0.35 & -2.64 & $-0.284^{\star \star}$ \\
\hline Constant & $4.40^{\star \star \star}$ & 1.10 & 4.05 & - \\
\hline Log likelihood function & \multicolumn{4}{|c|}{-52.61} \\
\hline LR chi2 & \multicolumn{4}{|c|}{88.03} \\
\hline Prod $>$ chi2 & \multicolumn{4}{|c|}{0.000} \\
\hline Pseudo $R^{2-}$ & \multicolumn{4}{|c|}{0.46} \\
\hline Observations (n) & \multicolumn{4}{|c|}{150} \\
\hline
\end{tabular}

Reasons of participation. According to the Table 5 the majority of the respondents $(79 \%)$ mentioned that low income from agriculture is the major reason for participating in offfarm activity in the study areas. Burden of maintaining large family was ranked second most important reason for participating in off-farm activity followed by availability of off-farm work opportunity.

Table 5. Reasons for participating in off-farm activities

\begin{tabular}{|c|c|c|c|}
\hline \multirow{2}{*}{ Reasons } & \multicolumn{3}{|c|}{$\%$ of farmers } \\
\hline & Jessore & Rangpur & All areas \\
\hline Burden of large family & 80 & 77 & 77 \\
\hline Low income from agriculture & 76 & 83 & 79 \\
\hline Available opportunities & 67 & 53 & 60 \\
\hline
\end{tabular}

\section{CONCLUSION}

The findings of the study reveal that on an average service holders received higher annual income compared to other categories of respondents. Farm size, infrastructure development and education had significant contribution in promoting off-farm activities like business and service whereas these factors are inversely related with off-farm labour activities. Low income and large family were the reasons for participating in off-farm activities in the study areas. Government and concerned authority should provide efficient support services to the farmers and build roads and highway to ensure participation in off-farm activities. By promoting this sector, farmers will be able to get sufficient amount of income which in turn may be used for investment in the farm practices. Off-farm activities may be used as a means of income diversification which will help to reduce poverty and boost the rural economy as a whole. 


\section{REFERENCES}

[1] Bhattacharya, D. 1996. The emerging pattern of rural non-farm sector in Bangladesh: A Review of Micro Evidence. The Bangladesh Development Studies, 24 (3-4), 143180.

[2] Child, F.C., and H. Kaneda. 1975. Links to the green revolution: A study of smallscale agriculturally related industry in the Pakistan Punjab. Economic Development and Cultural Change, 23 (2): 249-275.

[3] Haggblade, S., Hazell, P.B., Reardon, T. 2007. Transforming the Rural Off-farm Economy, Johns Hopkins University Press, Baltimore, MD.

[4] Hossain, M., 2005. Growth of the rural non-farm economy in Bangladesh: determinants and impact on poverty reduction. In: Proceedings of International conference 'Rice is life: scientific perspectives for the 21st century', 436-439.

[5] Hossain, M. Rahman, M. Bayes A. 1994. Rural off-farm Economy in Bangladesh: a Dynamic Sector or a Sponge of Absorbing Surplus Labor? SAAT Working Paper, International Labor Organization, New Delhi.

[6] Islam, R. 1984. Off-farm Employment in Rural Asia: Dynamic Growth or Proletarization? Journal of Contemporary Asia. Vol. 14: 306-324.

[7] Khandker, Shahidur R.1996. Role of targeted credit in rural non-farm growth. The Development Studies, 24(3-4), 181-193.

[8] Lanjouw, P. 2001. Rural non-agricultural sector and poverty in El Salvador. World Development, 29(3): 529-527.

[9] Mandal, M. A. Sattar and M. Assaduzzaman. 2002. Rural Off-farm Economy in Bangladesh: Characteristics, Issues and Livelihood Strategies for the Poor, Farm Economy, Vol. 12: 43-61.

[10] Ranis, G., and F. Stewart. 1993. Rural non-agricultural activities in development: Theory and application. Journal of Development Economics 40: 75-201.

[11] Reardon T. 1997. Using evidence of household income diversification to inform study of the rural nonfarm labor market in Africa. World Development, 25 (5) 735-748.

[12] The Financial Express. 2012. Non farm Employment in Rural Bangladesh, March 31, Bangladesh.

[13] Weijland H. 1999. Microenterprise clusters in rural Indonesia: Industrial seedbed and policy target. World Development, 27 (9): 1515-1530. 